Article

\title{
3-Acetyloxy-2-cyano-2-(alkylaminocarbamoyl)propyl Groups as Biodegradable Protecting Groups of Nucleoside 5'-mono-Phosphates
}

\author{
Mikko Ora *, Anne Mäntyvaara and Harri Lönnberg \\ Department of Chemistry, University of Turku, FIN-20014 Turku, Finland \\ * Author to whom correspondence should be addressed; E-Mail: mikora@utu.fi; \\ Tel.: +358-2133316706; Fax: +358-2-333-6700.
}

Received: 22 November 2010; in revised form: 30 December 2010 / Accepted: 13 January 2011 / Published: 14 January 2011

\begin{abstract}
Thymidine 5'-bis[3-acetyloxy-2-cyano-2-(2-phenylethylcarbamoyl)propyl] phosphate (1) has been prepared and the removal of phosphate protecting groups by hog liver carboxyesterase (HLE) at $\mathrm{pH} 7.5$ and $37{ }^{\circ} \mathrm{C}$ has been followed by HPLC. The first detectable intermediates are the $\left(R_{\mathrm{P}}\right)$ - and $\left(S_{\mathrm{P}}\right)$-diastereomers of the monodeacetylated triester 14, which subsequently undergo concurrent retro-aldol condensation to diester 4 and enzyme-catalyzed hydrolysis to the fully deacetylated triester $\mathbf{1 5}$. The former pathway predominates, representing $90 \%$ of the overall breakdown of 14 . The diester 4 undergoes the enzymatic deacetylation 700 times less readily than the triester, but gives finally thymidine 5'-monophosphate as the desired main product. To elucidate the potential toxicity of the electrophilic 2-cyano- $N$-(2-phenylethyl)acrylamideby-product 17 released upon the deprotection, the hydrolysis of $\mathbf{1}$ has also been studied in the presence of glutathione (GSH).
\end{abstract}

Keywords: prodrug; nucleotide; biodegradable; protecting group

\section{Introduction}

Masking of the ionic phosphate moiety of nucleotide analogues with enzyme-labile protecting groups offers a viable prodrug approach [1-6]. Enzymatic deacylation of one of the masking groups of a nucleoside $5^{\prime}$-phosphotriester triggers a concomitant chemical cleavage of the remnants of the 
protecting group, yielding nucleoside 5'-phosphodiester [7-23]. The negatively charged diester undergoes enzymatic deacylation much less readily than the parent triester [24-28], and hence, this latter step constitutes a bottleneck for the release of the 5 '-monophosphate. Our previous results with nucleoside $5^{\prime}$-phosphotriesters $\mathbf{2}$ and $\mathbf{3}$ and the respective diesters 5 and $\mathbf{6}$ have revealed that even a rather small structural modification, viz. introduction of an additional $-\mathrm{CH}_{2} \mathrm{O}$ - group between the enzyme labile ester function and the 2,2-diethoxycarbonyl substituted propyl group, accelerates the enzymatic deacetylation of both the triester and diester [29]. When using hog liver carboxyesterase, the acceleration is 40 -fold. In fact, the deacetylation of diester $\mathbf{5}$ is already so rapid that the subsequent chemical step, viz. departure of 3-hydroxy-2,2-bis(ethoxycarbonyl)propyl group by retro-aldol condensation (Scheme 1), becomes rate-limiting. The rate of this step may, however, be tuned within wide limits by the polar nature of the 2-substituents [30-33]. For example, 2-cyano-2-carbamoyl disubstitution markedly accelerates the retro-aldol condensation compared to bis(ethoxycarbonyl) substitution. The primary aim of the present study is to find out whether this combination of 2substituents also allows so facile enzymatic deacetylation of the diester that, taken together with rapid chemical retro-aldol condensation, an efficient pro-drug strategy is obtained. For this purpose, thymidine 5'-bis[3-acetyloxy-2-cyano-2-(2-phenylethylcarbamoyl)propyl]phosphate (1) has been prepared as a model compound and its hydrolysis initiated by hog liver carboxyesterase (HLE) has been followed by HPLC.

Scheme 1. Structures of compounds 1-6.
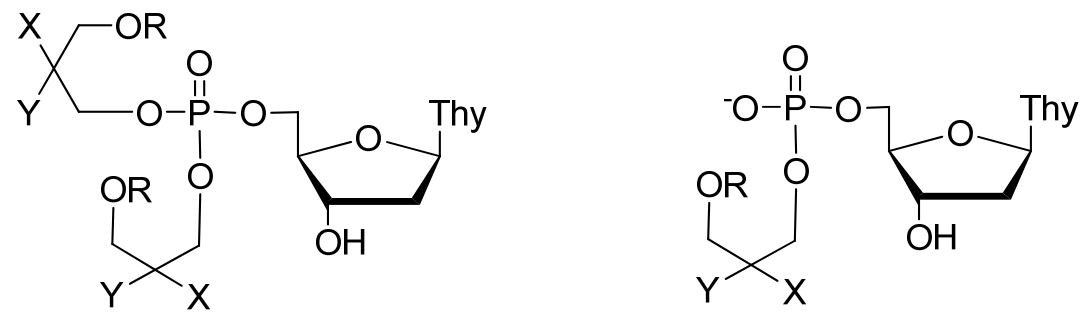

$$
\begin{aligned}
& \text { 1: } X=C N, Y=C O N H\left(\mathrm{CH}_{2}\right)_{2} \mathrm{Ph}, \mathrm{R}=\mathrm{Ac} \\
& \text { 2: } X=Y=\mathrm{CO}_{2} E t, R=\mathrm{CH}_{2} \mathrm{OAc} \\
& \text { 3: } X=Y=\mathrm{CO}_{2} E t, R=A c
\end{aligned}
$$

$$
\begin{aligned}
& \text { 4: } X=\mathrm{CN}, Y=\mathrm{CONH}\left(\mathrm{CH}_{2}\right)_{2} \mathrm{Ph}, \mathrm{R}=\mathrm{Ac} \\
& \text { 5: } \mathrm{X}=\mathrm{Y}=\mathrm{CO}_{2} E t, \mathrm{R}=\mathrm{CH}_{2} \mathrm{OAc}
\end{aligned}
$$$$
\text { 6: } X=Y=\mathrm{CO}_{2} E t, R=A c
$$

The potentially toxic by-products, such as formaldehyde and electrophilic alkylating agents, released upon breakdown of the biodegradable protecting groups form a general problem of pro-drug strategies. These by-products are believed to be captured by glutathione (GSH) present in cells at a high concentration. For example, aryl vinyl ketones released from HepDirectprodrugs in hepatocytes have been shown to undergo rapid conjugation with GSH in the mice serum [34]. Glutathione has also been proposed to react with formaldehyde in human cells [35]. $S$-Hydroxymethylglutathione formed is oxidized by formaldehyde dehydrogenase to $S$-formylglutathione which is further hydrolyzed to formate by $S$-formylglutathione hydrolase, regenerating free GSH [36]. The secondary aim of the present study is to evaluate the alkyating ability of 2-cyano- $N$-(2-phenylethyl)acrylamide (17) formed upon the deprotection of $\mathbf{1}$. For this reason, the HLE-triggered deprotection in the presence of GSH has been followed by HPLC-ESI-MS. 


\section{Results and Discussion}

\subsection{Synthesis}

2-cyano- $N$-(2-phenylethyl)acetamide (7), prepared from ethyl cyanoacetate by acyl substitution with (2-phenylethyl)amine, was bis(hydroxymethylated) by a procedure described earlier [37]. The 2cyano-3-hydroxy-2-(hydroxymethyl)- $N$-(2-phenylethyl)propanamide (8) thus obtained was then converted to orthoacetate 9 and finally hydrolyzed to 3-acetyloxy-2-cyano-2-hydroxymethyl- $N$-(2phenylethyl)propanamide (10), essentially as described earlier (Scheme 2) [38]. Alcohol 10 was isolated and used in tetrazole promoted alcoholysis of $3^{\prime}-O$-levulinoylthymidine $5^{\prime}-(N, N-$ diethylaminophosphoramidite (12) [29] (Scheme 3). The phosphite ester obtained was oxidized with iodine in a mixture of THF, water and lutidine to the corresponding phosphate ester $\mathbf{1 3}$ and the levulinoyl protecting group was removed with hydrazinium acetate in a mixture of dichloromethane and $\mathrm{MeOH}$.

Scheme 2. Preparation of 3-acetyloxy-2-cyano-2-hydroxymethyl- $N$-(2-phenylethyl)propanamide (10).<smiles>CCOC(=O)CC#N</smiles><smiles>NCCc1ccccc1</smiles><smiles>CCCC(=O)NCCc1ccccc1</smiles><smiles>N#CC(CO)(CO)C(=O)NCCc1ccccc1</smiles><smiles>CCOC1(C)OCC(C#N)(C(=O)NCCc2ccccc2)CO1</smiles><smiles>CC(=O)OCC(C#N)(CO)C(=O)NCCc1ccccc1</smiles>

i) $\mathrm{Et}_{3} \mathrm{~N}$; ii) $\mathrm{HCOH}, 1$,4-dioxan, $\mathrm{Et}_{3} \mathrm{~N} / \mathrm{THF}$; iii) (EtO) ${ }_{3} \mathrm{CCH}_{3}, \mathrm{H}_{2} \mathrm{SO}_{4}, \mathrm{THF}$; iv) $80 \% \mathrm{AcOH}$

Scheme 3. Preparation of thymidine 5'-bis[3-acetyloxy-2-cyano-2-(2-phenylethylcarbamoyl)propyl]phosphate (1).

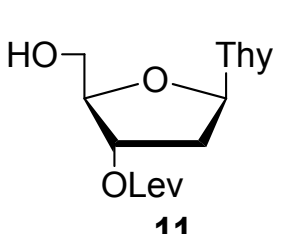

11<smiles>CCNP(Cl)NCC</smiles>

$\mathrm{Et}_{2} \mathrm{~N}$<smiles>CCNP(C)OCC1OC2CC([In])C(O2)C1O</smiles>

12

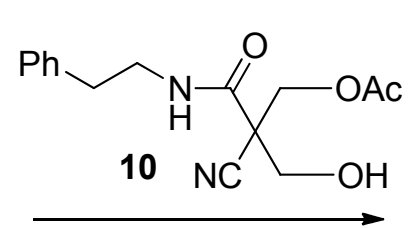

ii, iii

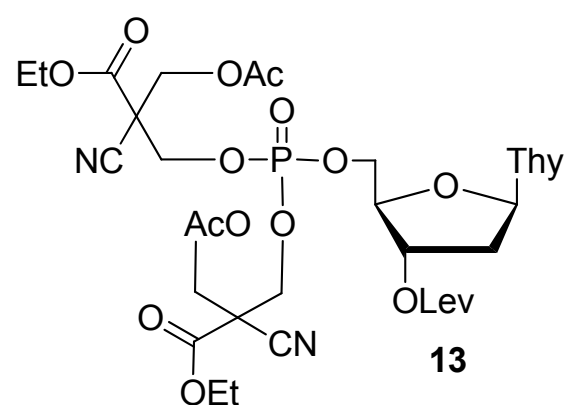

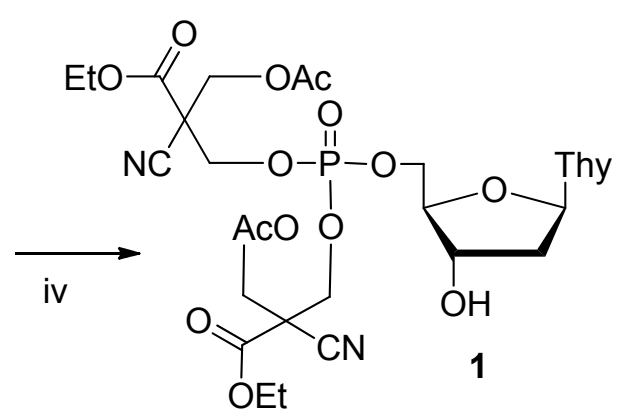

i) $\mathrm{Et}_{3} \mathrm{~N}, \mathrm{DCM}$; ii) TetH, MeCN; iii) $\mathrm{I}_{2}$, THF, $\mathrm{H}_{2} \mathrm{O}$ lutidine; iv) $\mathrm{NH}_{2} \mathrm{NH}_{2} \mathrm{OAc}, \mathrm{DCM}, \mathrm{MeOH}$ 
2.2. Hydrolytic Stability of Thymidine 5'-Bis[3-acetyloxy-2-cyano-2-(2-phenylethylcarbamoyl)propyl] phosphate (1)

Hydrolysis of triester 1 was studied at $\mathrm{pH} 7.5$ and $37{ }^{\circ} \mathrm{C}$ by analyzing the composition of the aliquots withdrawn from the reaction mixture at appropriate time intervals by RP HPLC. The products formed were identified by spiking with authentic samples and by mass spectrometric analysis (HPLC/ESI-MS). At pH 7.5-10, hydrolysis of the first acetic ester linkages of 1 (Reaction A in Scheme 4) was first-order in hydroxide-ion concentration. At $\mathrm{pH} \mathrm{7.5,} \mathrm{the} \mathrm{half-life} \mathrm{for} \mathrm{the} \mathrm{reaction} \mathrm{was} 28 \mathrm{~h}$ $\left(k=7.0 \times 10^{-6} \mathrm{~s}^{-1}\right)$. The subsequent departure of the remnants of this protecting group by retro-aldol condensation gave diester 4 (Route $C$ ) without accumulation of the monodeacetylated triester $\mathbf{1 4}$ as an intermediate. Hydrolysis of the second ester linkage (Reaction D) was 16 times slower, the half-live being $460 \mathrm{~h}$. Accordingly, the compound is slightly more stable than the corresponding 3-acetyloxymethoxy-2,2-bis(ethoxycarbonyl)propyl derived triester 2 . The half-lives for the consecutive deacetylations of 2 have been reported to be $32 \mathrm{~h}$ and $148 \mathrm{~h}$ under these conditions [29]. The 3acetyloxy-2,2-bis(ethoxycarbonyl)propyl protected triester $\mathbf{3}$ and its diester counterpart $\mathbf{6}$ are considerably more stable, the half-lives for the disappearance of $\mathbf{3}$ and $\mathbf{6}$ at $\mathrm{pH} 7.5$ and $25{ }^{\circ} \mathrm{C}$ being $480 \mathrm{~h}$ and $3850 \mathrm{~h}$, respectively [29].

Figure 1. RP-HPLC profiles for the HLE-catalyzed hydrolysis of thymidine 5'-bis[3acetyloxy-2-cyano-2-(2-phenylethylcarbamoyl)propyl]phosphate (1) at $\mathrm{pH} 7.5$ and $37.0{ }^{\circ} \mathrm{C}$ ( $I=0.1 \mathrm{~mol} \mathrm{~L}^{-1}$ with $\mathrm{NaCl}$ ). Notation: (a) 1, (b) 14, (c) 15, (d) 4, (e) 16, (f) thymidine and (g) 5'-TMP. For detailed chromatographic conditions, see the experimental section.

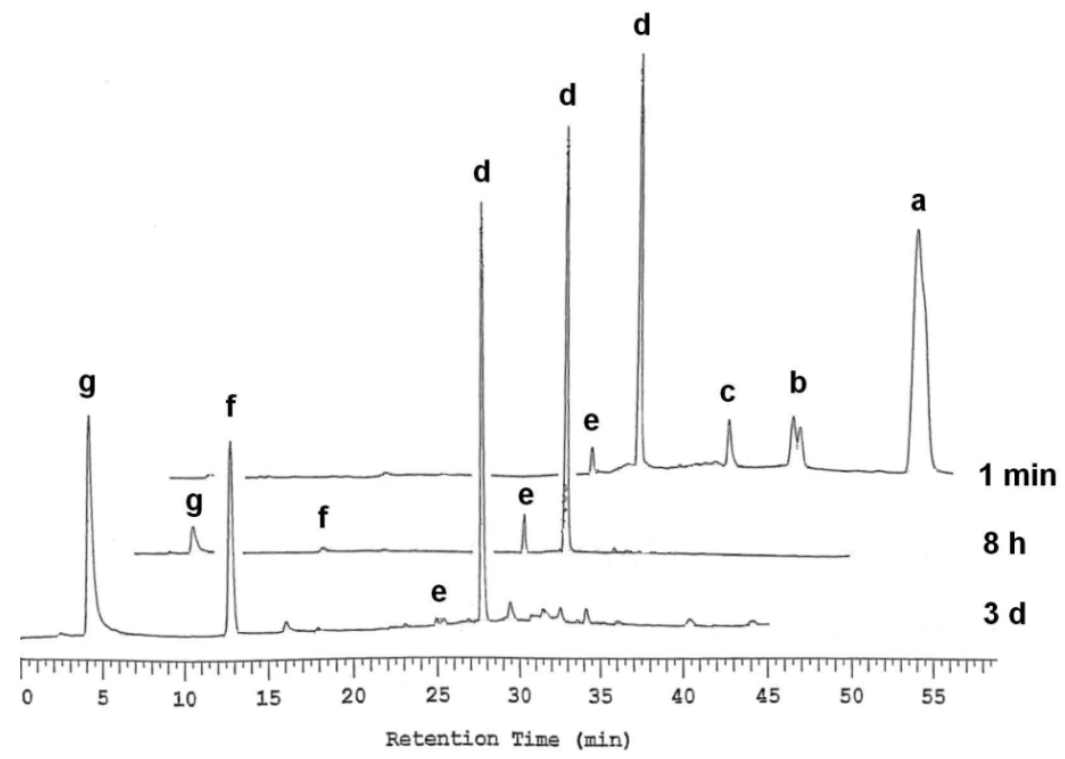

2.3. Enzymatic Deprotection of Thymidine 5'-Bis[3-acetyloxy-2-cyano-2-(2-phenylethylcarbamoyl)propyl]phosphate (1)

Treatment of triester $\mathbf{1}$ with hog liver carboxyesterase (26.0 units $\left.\mathrm{mL}^{-1}\right)$ in a 2-[4-(2hydroxyethyl)piperazin-1-yl)]ethanesulfonic acid (HEPES) buffer $(3.5 \mathrm{~mL})$ at $\mathrm{pH} 7.5$ and $37{ }^{\circ} \mathrm{C}$ 
( $I=0.1 \mathrm{~mol} \mathrm{~L}^{-1}$ with $\mathrm{NaCl}$ ) resulted in an intermediary accumulation of the $R_{\mathrm{P}}$ and $S_{\mathrm{P}}$-distereomers of monodeacetylated triester $14\left([\mathrm{M}+\mathrm{H}]^{+}=825.7\right.$; Reaction A in Scheme 4), the half-life for the disappearance of 1 (Reaction A) being $3.8 \mathrm{~min}$. The subsequent retro-aldol condensation of 14 to diester $4\left([\mathrm{M}+\mathrm{H}]^{+}=595.3\right.$; Reaction $\left.\mathrm{C}\right)$ was, however, so fast that the amount of $\mathbf{1 4}$ remained less than $5 \%$ of the initial concentration of 1 .

Scheme 4. Degradation pathway of thymidine 5'-bis[3-acetyloxy-2-cyano-2-(2phenylethylcarbamoyl)propyl]phosphate (1).

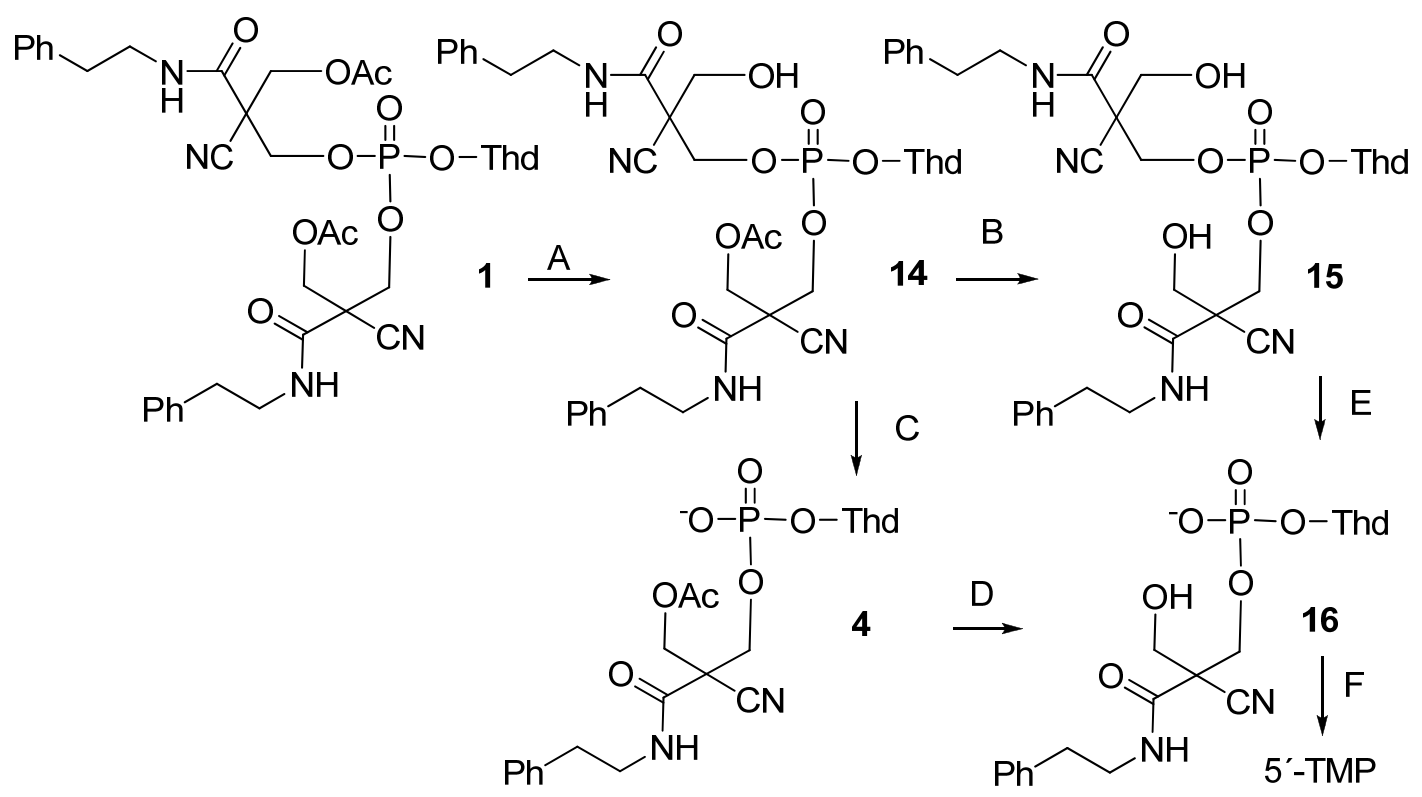

Deacetylation of $\mathbf{1 4}$ to the dideacetylated triester $\mathbf{1 5}\left([\mathrm{M}+\mathrm{H}]^{+}=783.8\right.$; Reaction $\left.\mathrm{B}\right)$ competed with the retro-aldol condensation, representing approximately $10 \%$ of the total disappearance of $\mathbf{1 4}$. Both, 4 and 15 were subsequently decomposed to diester $16\left([\mathrm{M}+\mathrm{H}]^{+}=553.3\right.$; Reactions D and E) that was rapidly converted to $5^{\prime}$-TMP $\left([\mathrm{M}+\mathrm{H}]^{+}=323.4\right.$; Reaction $\left.\mathrm{F}\right)$. The half-life for the disappearance of 4 was $47 \mathrm{~h}$. The level of accumulation of the deacetylated intermediate $\mathbf{1 6}$ remained below 5\%. Prolonged treatment with the esterase resulted in dephosphorylation of 5'-TMP to thymidine. Figure 1 gives as illustrative examples the chromatograms obtained at an early, intermediate and final stage of the deprotection of $\mathbf{1}$.

Table 1 records the half-lives obtained for the various partial reactions with $\mathbf{1}$ and its 3-acetyloxy2,2-bis(ethoxycarbonyl) and 3-acetyloxymethoxy-2,2-bis(ethoxycarbonyl) counterparts $\mathbf{3}$ and $\mathbf{2}$, respectively. Although at the high HLE concentration employed the rates of Reactions $\mathrm{B}$ and $\mathrm{C}$ are comparable, Reaction $\mathrm{C}$ predominates at low enzyme concentrations. Comparison of the half-lives of Reaction D reveals that $\mathbf{1}$ is under such conditions converted to $5^{\prime}$-TMP 3 times as fast as $\mathbf{3}$, but still one order of magnitude more slowly than 2 . The advantage of faster retro-aldol condensation of the intermediated derived from $\mathbf{1}$ is overcompensated by the slower enzymatic deacetylation of diester $\mathbf{4}$. In other words, the desired overall acceleration of the exposure of $5^{\prime}$-TMP was not achieved. 
Table 1. Half-lives for the partial reactions involved in hydrolysis of thymidine 5'-bis[3acetyloxy-2-cyano-2-(2-phenylethylcarbamoyl)propyl]phosphate (1) to $5^{\prime}$-TMP at pH 7.5 and $37^{\circ} \mathrm{C}\left(I=0.1 \mathrm{~mol} \mathrm{~L}^{-1}\right.$ with $\left.\mathrm{NaCl}\right)$. For the reactions, see Scheme 4. [HLE] $=26 \mathrm{units}_{\mathrm{mL}}^{-1}$. The corresponding half-lives reported previously [29] for thymidine 5'-bis[3acetyloxymethoxy-2,2-bis(ethoxycarbonyl)propyl]phosphate (2) and thymidine 5'-bis[3acetyloxy-2,2-bis(ethoxycarbonyl)propyl]phosphate (3) are included for reference.

\begin{tabular}{|c|c|c|c|}
\hline & \multicolumn{3}{|c|}{$\boldsymbol{t}_{\mathbf{1 / 2}} / \mathbf{m i n}$} \\
\hline Reaction & $\mathbf{1}$ & $\mathbf{2}$ & $\mathbf{3}$ \\
\hline $\mathrm{A}$ & 3.8 & 0.17 & 3.2 \\
\hline $\mathrm{D}$ & 2838 & 210 & 9060 \\
\hline $\mathrm{B}$ & $\approx 2$ & 0.90 & $31^{\mathrm{a}}$ \\
\hline C & $\approx 0.2$ & 10.4 & $31^{\mathrm{a}}$ \\
\hline
\end{tabular}

${ }^{\mathrm{a}} 25^{\circ} \mathrm{C}$.

\subsection{Reactions of 2-cyano-N-(2-phenyl)Ethylacrylamide with Glutathione}

As discussed above, retro-aldol condensation of the deacetylated intermediates, 14, 15 and 16, evidently produces 2-cyano- $N$-(2-phenyl)ethylacrylamide (17; Scheme 5). Consistent with this suggestion, an $\mathrm{m} / \mathrm{z}$ value of 199.2 , referring to the molecular ion [M-H] ${ }^{-}$of 17 , could be observed by the HPLC-ESI-MS analysis, but accumulation of this enone-like structure could not be verified by HPLC during the course of the hydrolysis of $\mathbf{1}$. It should be, in addition, noted that the same molecular ion is also obtained from cyclic products $\mathbf{2 0}$ and 21, formed by an intramolecular attack of either the amido oxygen (Route $\mathrm{H}$ ) or nitrogen (Route $\mathrm{G}$ ) on the $\beta$-carbon of $\mathbf{1 7}$. In fact, the signals at $\mathrm{m} / \mathrm{z} 199.2$ could be observed at different elution times. The mass spectra of these compounds additionally exhibited an unidentified $\mathrm{m} / z$ peak of 187.2. The $\mathrm{m} / z$ values $\left([\mathrm{M}+\mathrm{H}]^{+}=219.5\right.$ and $\left.[\mathrm{M}-\mathrm{H}]^{-}=217.2\right)$ referring to the molecular ion of 2-cyano-3-hydroxy- $N$-(2-phenyl)ethylpropanamide 19 (see Figure 2) was visible at the late stage of hydrolysis, and, hence, hydration of $\mathbf{1 7}$ may take place (Route F).

Scheme 5. Esterase-catalyzed hydrolysis of thymidine 5'-bis[3-acetyloxy-2-cyano-2-(2phenylethylcarbamoyl)propyl]phosphate (1) and reactions of 2-cyano- $N-(2-$ phenyl)ethylacrylamide (17) by-product formed.

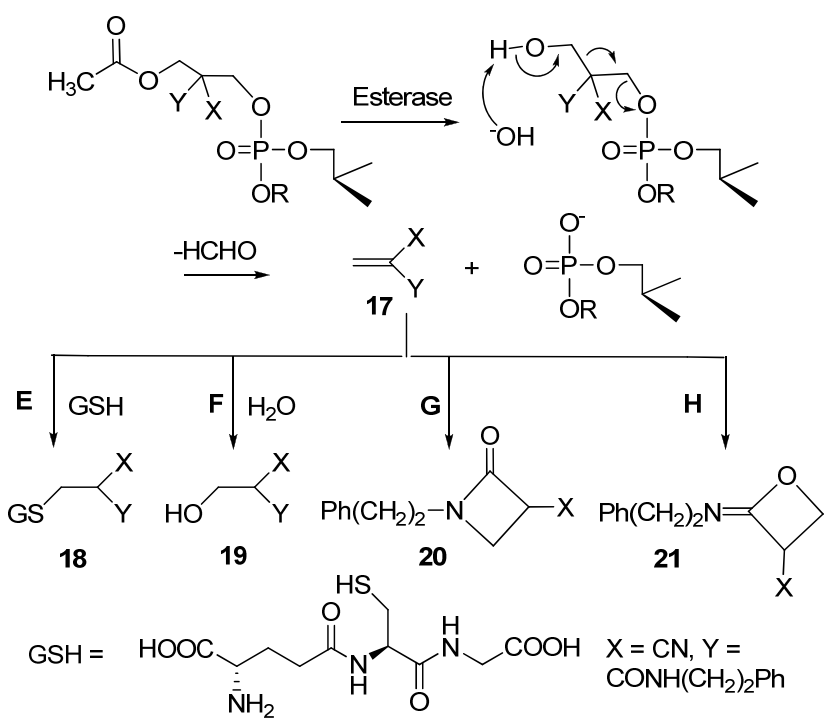


Figure 2. Inspection of mass spectra obtained from XIC $\mathrm{m} / z$ 217-218 (calcd. $[\mathrm{M}-\mathrm{H}]^{-}=217.1$ ) and 219-220 (calcd. $[\mathrm{M}+\mathrm{H}]^{+}=219.1$ ) for 19 during the hydrolysis of 1 (at $t=2 \mathrm{~d}$ ) in the presence HLE at pH 7.5 and $37^{\circ} \mathrm{C}$. Chromatographic conditions: A mixture of water and $\mathrm{MeCN}$ containing $0.1 \%$ formic acid (linear gradient from $2 \%$ up to $60.0 \% \mathrm{MeCN}$ in $35 \mathrm{~min}$ ).
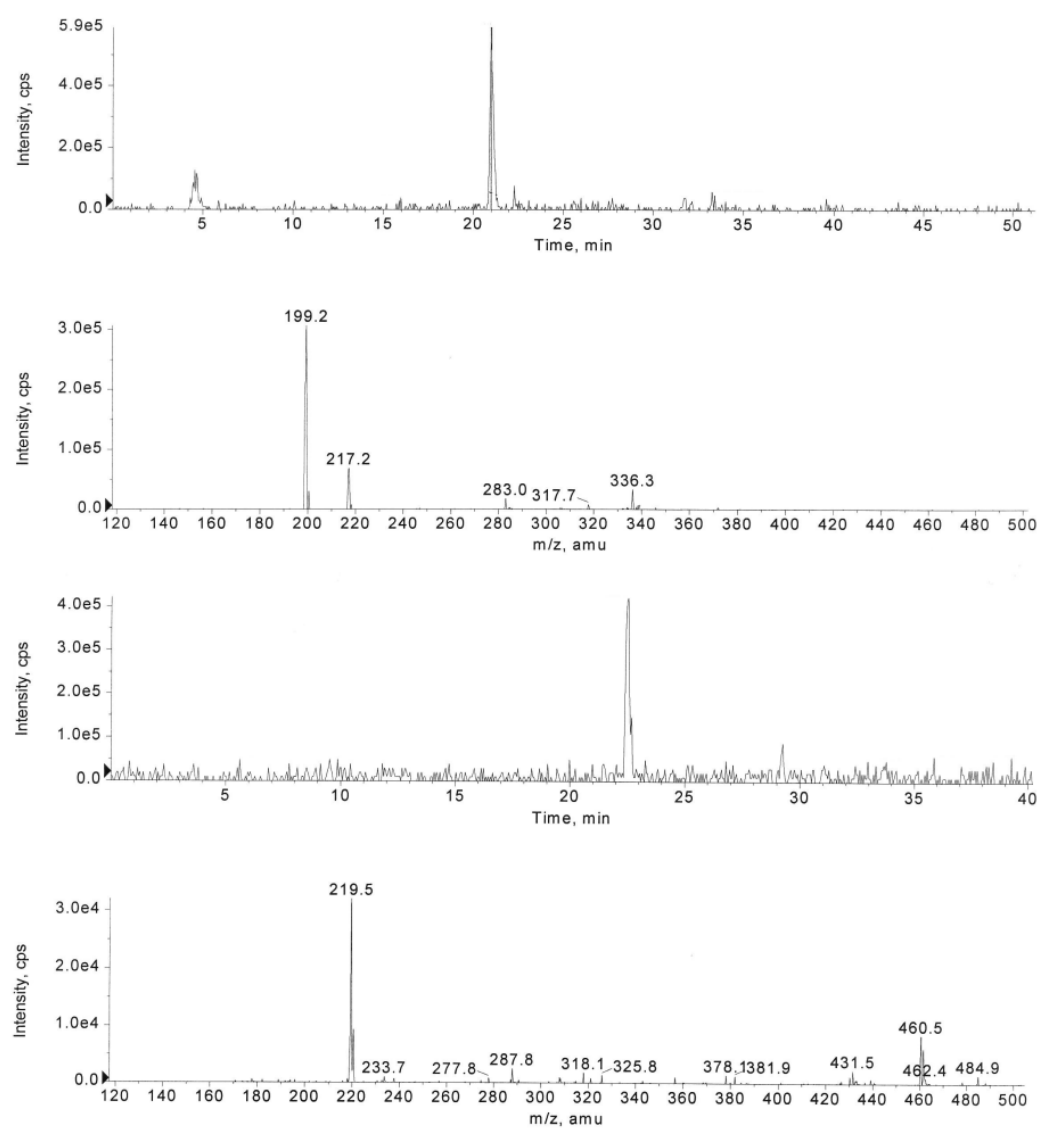

The hydrolytic reactions of 1 was also carried out in the presence of glutathione $([\mathrm{GSH}]=5.4 \mathrm{mM})$ and carboxyesterase $\left([\mathrm{HLE}]=28.0\right.$ units $\left.\mathrm{mL}^{-1}\right)$ in a 2 - $(N$-morpholino)ethanesulfonic acid (MES) buffer $\left(0.005 / 0.005 \mathrm{~mol} \mathrm{~L}^{-1}\right)$ at $\mathrm{pH} 6.2$ and $37^{\circ} \mathrm{C}$. Under these conditions, the half-live for the deacetylation of 1 was 18 h. In 2 days, the starting material was converted almost quantitatively to a mixture of acetylated and deacetylated phosphodiester 4 and 16 ([4]/[16] is 1:1). At this stage, 2-cyano- $N$-(2phenyl)ethylacrylamide (17) was captured as the glutathione conjugate $\left(\mathbf{1 8} ; t_{\mathrm{R}}=24.3 \mathrm{~min}\right.$, Route E). Product 18 was detected by both HPLC and LC-MS analysis $\left([\mathrm{M}+\mathrm{H}]^{+}=508.8\right.$; see Figure 3$)$. In addition, glutathione was converted to its oxidized form glutathione disulfide (GSSG; $[\mathrm{M}+\mathrm{H}]^{+}=613.5$ and $\left.t_{\mathrm{R}}=9.9 \mathrm{~min}\right)$.

Although 2-cyano- $N$-(2-phenyl)ethylacrylamide (17) is largely trapped by glutathione, cyclization (Routes $\mathrm{G}$ and $\mathrm{H}$ ) and hydration (Route $\mathrm{F}$ ) of $\mathbf{1 7}$ seem to occur as a side reaction. As seen from Figure 4, a $[\mathrm{M}-\mathrm{H}]^{-}$ion peak at $m / z 217.3$, referring most likely to 2-cyano-3-hydroxy- $N$-(2-phenyl)ethylpropanamide (19), appears and undergoes fragmentation (loss of $\mathrm{H}_{2} \mathrm{O}$ ) to yield an ion at $\mathrm{m} / \mathrm{z} 199.2$ (17). Similarly, the molecular ion signals of the cyclization products 20 and 21 ( $/$ /z 199.2) were detected as in the absence of GSH. By contrast, no sign of $S$-hydroxymethylglutathione, obtained by the reaction of GSH with formaldehyde, was observed. 
Figure 3. RP-HPLC profile for the glutathione conjugate of 2-cyano- $N$ phenethylacrylamide observed during the HLE-catalyzed hydrolysis of thymidine 5'-bis[3acetyloxy-2-cyano-2-(2-phenylethylcarbamoyl)propyl]phosphate(1) in the presence of $\mathrm{GSH}$ at $\mathrm{pH} 6.2$ and $37.0{ }^{\circ} \mathrm{C}$. Chromatographic conditions: A mixture of water and $\mathrm{MeCN}$ containing $0.1 \%$ formic acid (linear gradient from $1 \%$ up to $50.0 \% \mathrm{MeCN}$ in $35 \mathrm{~min}$ ). HPLC-signals were recorded on a UV detector at a wavelength of $215 \mathrm{~nm}$.

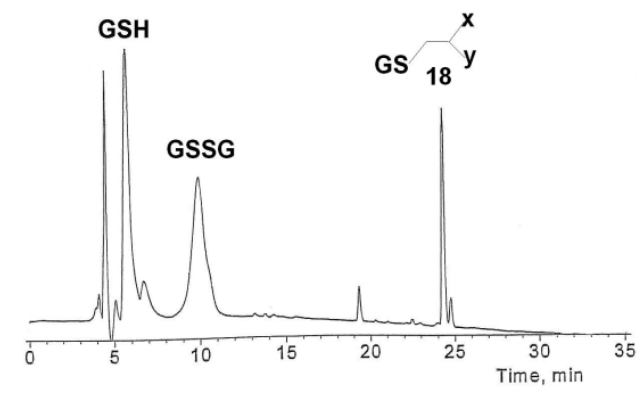

Figure 4. Inspection of mass spectra obtained from XIC $\mathrm{m} / \mathrm{z}$ 217-218 (calcd. $[\mathrm{M}-\mathrm{H}]^{-}=217.1$ ) and 199-200 (calcd. $[\mathrm{M}-\mathrm{H}]^{-}=199.1$ ) for 19, 20 and 21 during the hydrolysis of 1 (at $t=2 \mathrm{~d}$ ) in the presence of GSH and HLE at $\mathrm{pH} 6.2$ and $37{ }^{\circ} \mathrm{C}$. Chromatographic conditions: A mixture of water and $\mathrm{MeCN}$ containing $0.1 \%$ formic acid (linear gradient from $1 \%$ up to $50.0 \% \mathrm{MeCN}$ in $35 \mathrm{~min}$ ).
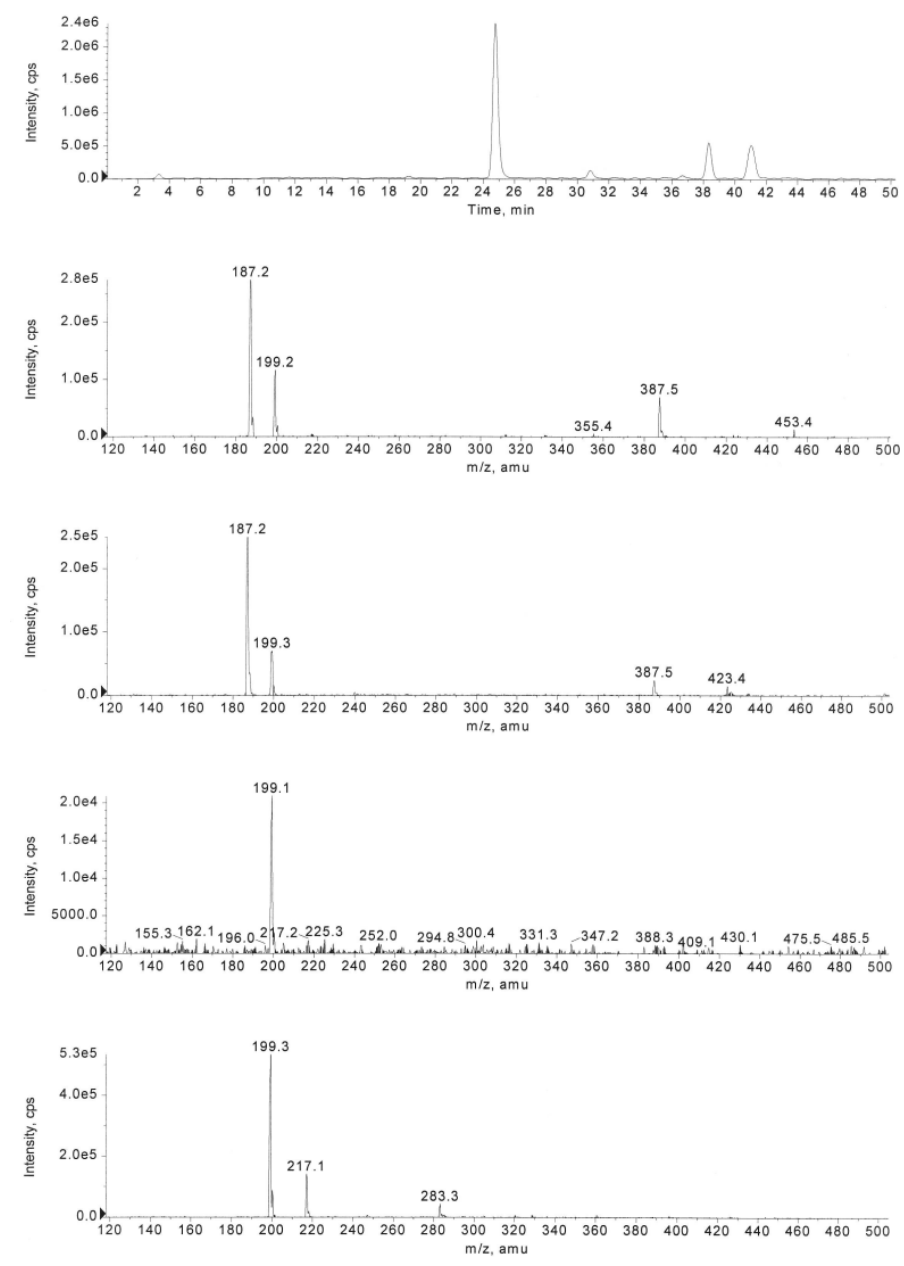


\section{Experimental}

\subsection{General}

Chemicals were purchased from Sigma-Aldrich, Fluka and Merck. Dichloromethane, acetonitrile, and pyridine were dried over $4 \AA$ molecular sieves. Dioxane was dried over $3 \AA$ molecular sieves. Triethylamine was dried by refluxing over $\mathrm{CaH}_{2}$ and distilled before use. ${ }^{1} \mathrm{H}-,{ }^{13} \mathrm{C}-,{ }^{31} \mathrm{P}-\mathrm{NMR}$ spectra were recorded on a Bruker Avance $400\left(400 \mathrm{MHz}\right.$ for ${ }^{1} \mathrm{H}, 101 \mathrm{MHz}$ for ${ }^{13} \mathrm{C}$ and $162 \mathrm{MHz}$ for $\left.{ }^{31} \mathrm{P}\right)$ or $500\left(500 \mathrm{MHz}\right.$ for ${ }^{1} \mathrm{H}, 126 \mathrm{MHz}$ for ${ }^{13} \mathrm{C}$ and $202 \mathrm{MHz}$ for ${ }^{31} \mathrm{P}$ ) NMR spectrometer. HRMS spectra were recorded on a Bruker Daltonics micrOTOF-Q instrument and LC-MS spectra were recorded on a Perkin-Elmer Sciex-API-365 triple-quadrupole instrument. For column chromatography, Fluka silica gel 60 (230-400 mesh) was used. Hydrolytic reactions were followed by Merck Hitachi LaChrom D7000 HPLC.

\subsection{Materials}

Hog liver carboxyesterase and glutathione were products of Fluka and Sigma, respectively. 3'-OLevulinoylthymidine (11) and 2-cyano-3-hydroxy-2-(hydroxymethyl)- $N$-(2-phenylethyl)propanamide (8) were prepared as described previously [33,37]. Protected thymidine 5'-monophosphates 1 was prepared by stepwise alcoholysis of bis(diethylamino)phosphorochloridite with 3'-Olevulinoylthymidine (11) and 2-cyano-2-(hydroxymethyl)-3-oxo-3-(phenethylamino)propyl acetate (10), a method that has previously been used for synthesis of $\mathbf{2}$ and 3 [29].

3'-O-Levulinoylthymidine (11) was prepared as described previously [31]. ${ }^{1} \mathrm{H}-\mathrm{NMR}(500 \mathrm{MHz}$, $\left.\mathrm{CDCl}_{3}\right): \delta=9.36(\mathrm{~s}$ broad, $1 \mathrm{H}, \mathrm{NH}), 7.73(\mathrm{~s}, 1 \mathrm{H}, \mathrm{H} 6), 6.25\left(\mathrm{dd}, 1 \mathrm{H}, J=6.5,2.0 \mathrm{~Hz}, \mathrm{H}^{\prime}\right), 5.37(\mathrm{~m}, 1 \mathrm{H}$, $\left.J=2.5 \mathrm{~Hz}, \mathrm{H} 3^{\prime}\right), 4.11$ (d, 1H, $\left.J=2.0 \mathrm{~Hz}, \mathrm{H} 4^{\prime}\right), 3.90$ (m, 2H, H5' and H5' $), 2.80$ (dt, $2 \mathrm{H}, J=6.0$, $\left.1.5 \mathrm{~Hz}, \mathrm{CH}_{2} \mathrm{Lev}\right), 2.59$ (t, 2H, $J=6.0 \mathrm{~Hz}, \mathrm{CH}_{2} \mathrm{Lev}$ ), 2.42 (m, 2H, H2' and H2' '), 2.22 (s, 3H, $\mathrm{CH}_{3}$ ), $1.92\left(\mathrm{~s}, 3 \mathrm{H}, \mathrm{CH}_{3} \mathrm{Lev}\right) .{ }^{13} \mathrm{C}-\mathrm{NMR}\left(126 \mathrm{MHz}, \mathrm{CDCl}_{3}\right): \delta=206.79(\mathrm{C}=\mathrm{O} \mathrm{Lev}), 172.61(\mathrm{C}=\mathrm{O} \mathrm{Lev})$, 164.11 (C4), 150.59 (C2), 136.59 (C6), 111.32 (C5), 86.04 (C1'), 85.08 (C4'), 74.96 (C3'), 62.47 (C5'), $37.83\left(\mathrm{C}^{\prime}\right), 37.15\left(\mathrm{CH}_{2} \mathrm{Lev}\right), 29.81\left(\mathrm{CH}_{2} \mathrm{Lev}\right), 27.95\left(\mathrm{CH}_{3} \mathrm{Lev}\right), 12.55\left(\mathrm{CH}_{3}\right) . \mathrm{ESI}^{+}-\mathrm{MS}$ : $\mathrm{m} /$ zobsd. $341.6[\mathrm{M}+\mathrm{H}]^{+}$, calcd. 341.1 .

2-cyano-3-hydroxy-2-(hydroxymethyl)-N-(2-phenylethyl)propanamide (8) was obtained as described previously [37]. ${ }^{1} \mathrm{H}-\mathrm{NMR}$ (400 MHz, DMSO): $\delta=7.98$ (t, 1H, $\left.J=5.6 \mathrm{~Hz}, \mathrm{NH}\right), 7.27(\mathrm{~m}, 2 \mathrm{H}, \mathrm{Ph}), 7.20$ $(\mathrm{m}, 3 \mathrm{H}, \mathrm{Ph}), 5.53(\mathrm{t}, 2 \mathrm{H}, J=5.6 \mathrm{~Hz}, 2 \times \mathrm{OH}), 3.70-3.63\left(\mathrm{~m}, 4 \mathrm{H}, J=5.6 \mathrm{~Hz}, 2 \times \mathrm{CH}_{2} \mathrm{O}\right), 3.30(\mathrm{~m}, 2 \mathrm{H}$, $\mathrm{CH}_{2} \mathrm{~N}$ ), 2.73 (t, 2H, $\left.\mathrm{CH}_{2} \mathrm{Ph}\right) .{ }^{13} \mathrm{C}$ NMR (101 MHz, DMSO): $\delta=165.79(\mathrm{C}=\mathrm{O}), 139.73(\mathrm{Ph}), 129.15$ $(\mathrm{Ph}), 128.79(\mathrm{Ph}), 126.58(\mathrm{Ph}), 120.15(\mathrm{CN}), 62.19\left(\mathrm{CH}_{2} \mathrm{O}\right), 55.73(\mathrm{C} 2), 41.52\left(\mathrm{CH}_{2} \mathrm{~N}\right), 35.36\left(\mathrm{CH}_{2} \mathrm{Ph}\right)$ ppm. $\mathrm{ESI}^{+}$-MS: $m / z[\mathrm{M}+\mathrm{Na}]^{+}$obsd. 271.2, calcd. 271.2 .

2-cyano-2-(hydroxymethyl)-3-oxo-3-(2-phenethylamino)propyl acetate (10). Concentrated $\mathrm{H}_{2} \mathrm{SO}_{4}$ $(8.4 \mu \mathrm{L}, 0.15 \mathrm{mmol})$ was added to a mixture of compound 8 (1.54 g, $6.2 \mathrm{mmol})$ and triethyl orthoacetate $(1.71 \mathrm{~mL}, 9.3 \mathrm{mmol})$ in dry THF $(10 \mathrm{~mL})$. The reaction was allowed to proceed overnight 
and the mixture was the poured into an ice-cold solution of $5 \% \mathrm{NaHCO}_{3}(50 \mathrm{~mL})$. The product was extracted with diethyl ether $(3 \times 50 \mathrm{~mL})$, washed with saturated aqueous $\mathrm{NaCl}$ $(3 \times 50 \mathrm{~mL})$ and dried over $\mathrm{Na}_{2} \mathrm{SO}_{4}$. The solvent was evaporated and the crude product, 5-cyano-2ethoxy-2-methyl- $N$-(2-phenyl)-ethyl-1,3-dioxane-5-carboxamide (9), was subjected to silica gel chromatography, eluting with a mixture of DCM and $\mathrm{MeOH}(90: 10, v / v)$. The product (9) was obtained as oil (1.5 g, 76\%). ${ }^{1} \mathrm{H}-\mathrm{NMR}$ (400 MHz, DMSO) $\delta=8.55,8.44,8.26,7.98$ (t each, $1 \mathrm{H}$, $J=5.5 \mathrm{~Hz}, \mathrm{NH}), 7.28(\mathrm{~m}, 2 \mathrm{H}, \mathrm{Ph}), 7.21(\mathrm{~m}, 3 \mathrm{H}, \mathrm{Ph}), 4.32,4.02,3.57,3.45$ (q each, $2 \mathrm{H}, J=7 \mathrm{~Hz}$, $\mathrm{CH}_{2} \mathrm{CH}_{3}$ ), 5.82, 5.81, 5.54, 5.53, 4.28, 4.23, 4.07, 3.99 (d each, $4 \mathrm{H}, J=5.5 \mathrm{~Hz}$ and $J=11.5 \mathrm{~Hz}$, $\mathrm{CH}_{2} \mathrm{O}$ ), 3.79-3.66 and 3.41-3.29 (m, 2H, $\left.J=6 \mathrm{~Hz}, \mathrm{CH}_{2} \mathrm{~N}\right), 2.77,2.74,2.56(\mathrm{t}$ each, $2 \mathrm{H}, J=7.5 \mathrm{~Hz}$, $\mathrm{CH}_{2} \mathrm{Ph}$ ), 2.03, 1.99, 1.421 .36 (s each, 3H, $\mathrm{CH}_{3}$ ), 1.33, 1.17, 1.15, 1.06 (t each, $3 \mathrm{H}, J=7.0 \mathrm{~Hz}$, $\left.\mathrm{CH}_{2} \mathrm{CH}_{3}\right) . \mathrm{ESI}^{+}-\mathrm{MS}$ : $m / z[\mathrm{M}+\mathrm{Na}]^{+}$obsd.341.3, calcd. 341.1 .

5-cyano-2-ethoxy-2-methyl-N-(2-phenyl)-ethyl-1,3-dioxane-5-carboxamide (9) (1.3 g, $4.08 \mathrm{mmol})$ was dissolved in $80 \%$ aqueous acetic acid $(50 \mathrm{~mL})$ and left for $1 \mathrm{~h}$ at room temperature. The solution was evaporated to dryness and the residue was coevaporated three times with water. The product was purified by silica gel colum chromatogaphy eluting with a mixture of DCM and $\mathrm{MeOH}(95: 5, v / v)$. The product (10) was obtained as solid foam $(1.2 \mathrm{~g}, 90 \%) .{ }^{1} \mathrm{H}-\mathrm{NMR}\left(400 \mathrm{MHz}, \mathrm{CDCl}_{3}\right): \delta=8.28(\mathrm{t}, 1 \mathrm{H}$, $J=5.6 \mathrm{~Hz}, \mathrm{NH}), 7.30(\mathrm{~m}, 2 \mathrm{H}, \mathrm{Ph}), 7.21(\mathrm{~m}, 3 \mathrm{H}, \mathrm{Ph}), 5.81(\mathrm{t}, 1 \mathrm{H}, J=5.6 \mathrm{~Hz}, \mathrm{OH}), 4.34(\mathrm{~s}, 2 \mathrm{H}$, $\left.\mathrm{CH}_{2} \mathrm{OAc}\right), 3.74\left(\mathrm{t}, 2 \mathrm{H}, J=5.2 \mathrm{~Hz}, \mathrm{CH}_{2} \mathrm{OH}\right), 3.31\left(2 \mathrm{H}, \mathrm{CH}_{2} \mathrm{~N}\right), 2.74\left(\mathrm{t}, 2 \mathrm{H}, J=7.6 \mathrm{~Hz}, \mathrm{CH}_{2} \mathrm{Ph}\right), 2.03$ $\left(\mathrm{s}, 3 \mathrm{H}, \mathrm{C}(\mathrm{O}) \mathrm{CH}_{3}\right) .{ }^{13} \mathrm{C}-\mathrm{NMR}\left(101 \mathrm{MHz}, \mathrm{CDCl}_{3}\right): \delta=170.05(\mathrm{C}=\mathrm{O} \mathrm{Ac}), 164.73(\mathrm{C}(\mathrm{O}) \mathrm{NH}), 137.93$ $(\mathrm{Ph}), 128.82(\mathrm{Ph}), 128.75(\mathrm{Ph}), 126.92(\mathrm{Ph}), 117.60(\mathrm{CN}), 63.41\left(\mathrm{CH}_{2} \mathrm{OAc}\right), 62.96\left(\mathrm{CH}_{2} \mathrm{OH}\right)$, 51.01(C2), $41.55\left(\mathrm{CH}_{2} \mathrm{NH}\right), 35.27\left(\mathrm{CH}_{2} \mathrm{Ph}\right), 20.54\left(\mathrm{CH}_{3}\right)$ ppm. ESI ${ }^{+}-\mathrm{MS}: m / z[\mathrm{M}+\mathrm{Na}]^{+}$obsd. 313.1146, calcd. 313.1159 .

Thymidine 5'-bis[3-acetyloxy-2-cyano-2-(2-phenylethylcarbamoyl)propyl]phosphate (1). 3'-OLevulinoylthymidine (11) was coevaporated three times from dry pyridine and dried on $\mathrm{P}_{2} \mathrm{O}_{5}$ overnight. To a solution of dried $11(0.15 \mathrm{~g}, 0.45 \mathrm{mmol})$ in dry DCM (1.2 $\mathrm{mL})$, anhydrous triethylamine $(0.32 \mathrm{~mL}, 2.27 \mathrm{mmol})$ and bis(diethylamino)chlorophosphine $(135 \mu \mathrm{L}, 0.64 \mathrm{mmol})$ was added, and the reaction mixture was stirred for $2 \mathrm{~h}$ under nitrogen. The product $\mathbf{1 2}$ was filtered through a short silica gel column eluting with a mixture of anhydrous ethyl acetate and triethylamine in hexane $(60: 0.5: 39.5, v / v / v)$. The solvent was removed under reduced pressure and the residue was coevaporated three times from dry $\mathrm{MeCN}$ to remove the traces of triethylamine. The residue $(0.16 \mathrm{~g})$ was dissolved in dry $\mathrm{MeCN}(0.5 \mathrm{~mL})$ and compound $10(0.44 \mathrm{~g}, 1.53 \mathrm{mmol})$ in dry $\mathrm{MeCN}(0.5 \mathrm{~mL})$ and tetrazole $\left(2.72 \mathrm{mmol} ; 6.10 \mathrm{~mL}\right.$ of $0.45 \mathrm{~mol} \mathrm{~L}^{-1}$ solution in $\mathrm{MeCN}$ ) were added under nitrogen. The reaction mixture was stirred for $4 \mathrm{~h}$ at room temperature. The phosphite ester $\mathbf{1 3}$ formed was oxidized with $\mathrm{I}_{2}\left(0.1 \mathrm{~mol} \mathrm{~L}^{-1}\right)$ in a mixture of THF, $\mathrm{H}_{2} \mathrm{O}$ and lutidine $(4: 2: 1, \mathrm{v} / \mathrm{v} / \mathrm{v} ; 7 \mathrm{~mL})$ by stirring overnight at room temperature. The crude product, 3'-O-levulinoylthymidine 5'-bis[3-acetyloxy-2-cyano-2-(2phenylethylcarbamoyl)propyl]phosphate (13) was isolated by $\mathrm{DCM} /$ aq. $\mathrm{NaHSO}_{3}$ work up, and purified on a silica gel column eluted with ethylacetate, followed by a stepwise gradient from a mixture of DCM and $\mathrm{MeOH}(98: 2, v / v)$ up to $30 \% \mathrm{MeOH}$. The purification was repeated using ethyl acetate and a mixture of DCM and $\mathrm{MeOH}(90: 10, v / v)$ as an eluent. The product (13) obtained as solid foam was contaminated by some unidentified impurities. The product was characterizied by HPLC-MS eluting 
with a mixture of water and $\mathrm{MeCN}$ (linear gradient from $10 \%$ up to $40.0 \% \mathrm{MeCN}$ in 40 min) (ESI ${ }^{+}$ MS: $\mathrm{m} / \mathrm{z}[\mathrm{M}+\mathrm{H}]^{+}$obsd. 965.3 calcd. 965.7 and $\left.t_{\mathrm{R}}=29.5 \mathrm{~min}\right)$ and used without further purification. Compound 13 was dissolved in dry DCM $(2.0 \mathrm{~mL})$ and hydrazine acetate $(0.11 \mathrm{mmol}, 10 \mathrm{mg})$ in dry $\mathrm{MeOH}(0.20 \mathrm{~mL})$ was added. After $1 \mathrm{~h}$, hydrazinium acetate $(0.05 \mathrm{mmol}, 4.6 \mathrm{mg})$ in a mixture of DCM $(100 \mu \mathrm{L})$ and $\mathrm{MeOH}(20 \mu \mathrm{L})$ was added. The reaction was allowed to proceed for $1.5 \mathrm{~h}$ and the addition of hydrazinium acetate was repeated. The reaction was quenched with acetone and the mixture was evaporated to dryness. The crude product was purified by reversed phase chromatography on a Lobar RP-18 column $(37 \times 440 \mathrm{~mm}, 40-63 \mu \mathrm{m})$, eluting with a mixture of water and acetonitrile $(60: 40 \%, v / v)$. The product was obtained as solid foam $(25 \mathrm{mg}, 43 \%)$. ${ }^{1} \mathrm{H}-\mathrm{NMR}\left(400 \mathrm{MHz}, \mathrm{CDCl}_{3}\right)$ : $\delta=8.65($ broad, $1 \mathrm{H}, \mathrm{NH}), 7.35-20(\mathrm{~m}, 11 \mathrm{H}, \mathrm{H} 6$ and $2 \times \mathrm{Ph}), 6.72\left(\mathrm{~m}, 2 \mathrm{H}, 2 \times \mathrm{CH}_{2} \mathrm{NH}\right), 6.15(\mathrm{~m}, 1 \mathrm{H}$, $\left.\mathrm{H}^{\prime}\right), 4.51-4.31\left(\mathrm{~m}, 11 \mathrm{H}, \mathrm{H} 3{ }^{\prime}, \mathrm{H}^{\prime}\right.$ ', H5' ${ }^{\prime \prime}$ and $\left.4 \times \mathrm{CH}_{2} \mathrm{O}\right), 4.00\left(\mathrm{~m}, 1 \mathrm{H}, \mathrm{H} 4{ }^{\prime}\right), 3.63(\mathrm{~m}, 2 \mathrm{H}, J=6.4 \mathrm{~Hz}$, $\left.\mathrm{CH}_{2} \mathrm{~N}\right), 3.51\left(\mathrm{~m}, 2 \mathrm{H}, J=6.7 \mathrm{~Hz}, \mathrm{CH}_{2} \mathrm{~N}\right), 2.86\left(\mathrm{~m}, 4 \mathrm{H}, J=6.8 \mathrm{~Hz}, 2 \times \mathrm{CH}_{2} \mathrm{Ph}\right), 2.32\left(\mathrm{~m}, 2 \mathrm{H}, \mathrm{H} 2^{\prime}\right.$ and $\left.\mathrm{H}^{\prime \prime}{ }^{\prime \prime}\right), 2.08\left(\mathrm{~s}, 6 \mathrm{H}, 2 \times \mathrm{C}(\mathrm{O}) \mathrm{CH}_{3}\right) 2.01\left(\mathrm{~s}, 3 \mathrm{H}, \mathrm{CH}_{3}\right) .{ }^{13} \mathrm{C}-\mathrm{NMR}\left(101 \mathrm{MHz}, \mathrm{CDCl}_{3}\right): \delta=169.69$ $(\mathrm{C}=\mathrm{OAc}), 163.58(\mathrm{C} 4), 162.34(\mathrm{C}(\mathrm{O}) \mathrm{NH}), 150.14(\mathrm{C} 2), 137.84(\mathrm{Ph}), 136.5(\mathrm{C} 6), 128.85(\mathrm{Ph}), 128.73$ $(\mathrm{Ph}), 126.93(\mathrm{Ph}), 116.79(\mathrm{CN}), 116.35(\mathrm{CN}), 111.33(\mathrm{C} 5), 85.76\left(\mathrm{C4}^{\prime}\right), 84.14\left(\mathrm{C}^{\prime}\right), 67.50\left(\mathrm{C3}^{\prime}\right)$, $67.08\left(\mathrm{C}^{\prime}\right), 62.72\left(\mathrm{CH}_{2} \mathrm{OAc}\right), 50.52\left(\mathrm{C}\right.$ spiro), $41.96\left(\mathrm{CH}_{2} \mathrm{NH}\right), 35.19\left(\mathrm{CH}_{2} \mathrm{Ph}\right), 26.86\left(\mathrm{C}^{\prime}\right), 20.49$ $\left(\mathrm{C}(\mathrm{O}) \mathrm{CH}_{3}\right), 12.45\left(\mathrm{CH}_{3}\right)$ ppm. ${ }^{31} \mathrm{P}-\mathrm{NMR}\left(162 \mathrm{MHz}, \mathrm{CDCl}_{3}\right): \delta=-2,53 ;-2,76 ;-3,17 ;-3,35 \mathrm{ppm}$ (The four phosphorus signals refer tothe presence of stereogenic center in each of the phosphate protecting groups). ESI ${ }^{+}-\mathrm{MS}: m / z[\mathrm{M}+\mathrm{H}]^{+}$obsd. 867.8 calcd. 867.3. ESI $^{+}-\mathrm{MS}: m / z[\mathrm{M}+\mathrm{Na}]^{+}$obsd. 889.2785, calcd. 889.2780.

\subsection{Kinetic Measurements}

The reactions were carried out in sealed tubes immersed in a thermostated water bath $\left(37.0 \pm 0.1^{\circ} \mathrm{C}\right)$. The oxonium ion concentration of the reaction solution $(3.5 \mathrm{~mL})$ was adjusted with glycine, 2-[4-(2-hydroxyethyl)piperazin-1-yl)]ethanesulfonic acid (HEPES) and 2-(N-morpholino)ethanesulfonic acid (MES) buffers. The ionic strength of the solutions was adjusted to $0.1 \mathrm{~mol} \mathrm{~L}^{-1}$ with sodium chloride. The hydronium ion concentration of the buffer solutions was calculated with the aid of the known $\mathrm{p} K_{\mathrm{a}}$ values of the buffer acid under the experimental conditions. The initial substrate concentration was ca. $0.4 \mathrm{mmol} \mathrm{L}^{-1}$.

The enzymatic hydrolysis was carried out with Hog Liver Esterase (26 units $\left.\mathrm{mL}^{-1}\right)$ in a 2-[4-(2-hydroxyethyl)piperazin-1-yl)] ethanesulfonic acid (HEPES) buffer $\left(0.040 / 0.024 \mathrm{~mol} \mathrm{~L}^{-1}\right)$ at $\mathrm{pH}$ 7.5 and $37^{\circ} \mathrm{C}$. The samples $(200 \mu \mathrm{L})$ withdrawn at appropriate intervals were made acidic $(\mathrm{pH} 2)$ with $1 \mathrm{~mol} \mathrm{~L}^{-1}$ aqueous hydrogen chloride to inactivate the enzyme and to quench the hydrolysis, cooled in an ice-bath and filtered with minisart RC 4 filters $(0.45 \mu \mathrm{m})$. The composition of the samples was analyzed on an ODS Hypersil C18 column $\left(4 \times 250 \mathrm{~mm} 5 \mu \mathrm{m}\right.$, flow rate $\left.1 \mathrm{~mL} \mathrm{~min}^{-1}\right)$, using a mixture of acetic acid/sodium acetate buffer $\left(0.045 / 0.015 \mathrm{~mol} \mathrm{~L}^{-1}\right)$ and $\mathrm{MeCN}$, containing ammonium chloride $\left(0.1 \mathrm{~mol} \mathrm{~L}^{-1}\right)$. A good separation of the product mixtures of 2 was obtained on using a 5 min isocratic elution with the buffer containing $2 \% \mathrm{MeCN}$, followed by a linear gradient (23 min) up to $40.0 \%$ $\mathrm{MeCN}$. Signals were recorded on a UV-detector at a wavelength of $267 \mathrm{~nm}$. The reaction products were identified by the mass spectra (LC/MS) using a mixture of water and acetonitrile containing a formic acid $(0.1 \%)$ as an eluent (Gemini C18 column $\left(2 \times 150 \mathrm{~mm} 5 \mu \mathrm{m}\right.$, flow rate $\left.200 \mu \mathrm{L} \mathrm{min}{ }^{-1}\right)$. The 
first order rate constants for the non-enzymatic hydrolysis of triester 1 were obtained by applying firstorder rate-law to the diminution of the concentration of the starting material. The enzymatic deacetylations obeyed first-order kinetics at the high HLE concentrations employed.

\section{Conclusions}

Thymidine 5'-phosphotriester 1 bearing two 3-acetyloxy-2-cyano-2-(alkylaminocarbonyl)propyl groups undergoes esterase triggered breakdown to $5^{\prime}$-TMP more readily than its 3-acetyloxy-2,2-bis(ethoxycarbonyl)propyl counterpart, but considerably less readily than the 3-acetyloxymethoxy-2,2bis(ethoxycarbonyl)propyl derived triester. The initial enzymatic deacetylation is followed by release of the resulting 3-hydroxy-2-cyano-2-(alkylaminocarbonyl)propyl group as 2-cyano- $N$-(2-phenylethyl)acrylamide (17). When the reaction is carried out in large excess of glutathione, 17 is largely converted to glutathione conjugate 18. In addition, intramolecular cyclization and hydration occur as side reactions.

\section{Acknowledgements}

The authors wish to thank Anna Rossi for assistance with HPLC analyses.

\section{References and Notes}

1. Hecker, S.J.; Erion, M.D. Prodrugs of phosphates and phosphonates. J. Med. Chem. 2008, 51, 2328-2345.

2. Poijärvi-Virta, P.; Lönnberg, H. Prodrug approaches of nucleotides and oligonucleotides. Curr. Med. Chem. 2006, 13, 3441-3465.

3. Mackman, R.L.; Cihlar, T. Prodrug strategies in the design of nucleoside and nucleotide antiviral therapeutics. Annu. Rep. Med. Chem. 2004, 39, 305-321.

4. Schultz, C. Prodrugs of biologically active phosphate esters. Bioorg. Med. Chem. 2003, 11, 885-898.

5. Anastasi, C.; Quelever, G.; Burlet, S.; Garino, C.; Souard, F.; Kraus, J.L. New antiviral nucleoside prodrugs await application. Curr. Med. Chem.2003, 10, 1825-1843.

6. Wagner, C.R.; Iyer, V.V.; McIntee, E.J. Pronucleotides: toward the in vivo delivery of antiviral and anticancer nucleotides. Med. Res. Rev. 2000, 20, 417-451.

7. Krecmerova, M.; Holy, A.; Pohl, R.; Masojidkova, M.; Andrei, G.; Naesens, L.; Neyts, J.; Balzarini, J.; De Clercq, E.; Snoeck, R. Ester prodrugs of cyclic 1-(S)-[3-hydroxy-2(phosphonomethoxy)propyl]-5-azacytosine: Synthesis and antiviral activity. J. Med. Chem. 2007, 50, 5765-5772.

8. Padmanabhan, S.; Coughlin, J.E.; Zhang, G.; Kirk, C.J.; Iyer, R.P. Anti-HBV nucleotide prodruganalogs: Synthesis, bio-reversibility, and cytotoxicity studies. Bioorg. Med. Chem. Lett. 2006, 16, 1491-1494.

9. Khan, S.R.; Nowak, B.; Plunkett, W.; Farquhar, D. Bis(pivaloyloxymethyl) thymidine 5'phosphate is a cell membrane-permeable precursor of thymidine 5'-phosphate in thymidine kinase deficient CCRF CEM cells. Biochem. Pharmacol. 2005, 69, 1307-1313. 
10. Choi, J.R.; Cho, D.G.; Roh, K.Y.; Hwang, J.T.; Ahn, S.; Jang, H.S.; Cho, W.Y.; Kim, K.W.; Cho, Y.G.; Kim, J.; Kim, Y.Z. A novel class of phosphonate nucleosides 9-((1phosphonomethoxycycloproyl)-methyl)-guanine as a potent and selective anti-Hbv agent. J. Med. Chem. 2004, 47, 2864-2869.

11. Rose, J.D.; Parker, W.B.; Someya, H.; Shaddix, S.G.; Montgomery, J.; Secrist III, J.A. Enhancement of nucleoside cytotoxicity through nucleotide prodrugs. J. Med. Chem. 2002, 45, 4505-4512.

12. Shaw, J.-P.; Louie, M.S.; Krishnamurthy, V.V.; Arimilli, M.N.; Jones, R.J.; Bidgood, A.M.; Lee, W.A.; Cundy, K.C. Pharmacokinetics and metabolism of selected prodrugs of PMEA in rats. Drug Metab. Dispos. 1997, 25, 362-366.

13. Starrett, J.E., Jr.; Tortolani, D.R.; Russell, J.; Hitchcock, M.J.M.; Whiterock, V.; Martin, J.C.; Mansuri, M.M. Synthesis, oral bioavailability determination, and in vitro evaluation of prodrugs of the antiviral agent 9-[2-(phosphonomethoxy)ethyl]adenine (PMEA). J. Med. Chem.1994, 37, 1857-1864.

14. Farquhar, D.; Khan, S.; Srivastava, D.N.; Saunders, P.P. Synthesis and antitumor evaluation of bis[(pivaloyloxy)methyl] 2'-deoxy-5-fluorouridine 5'-monophosphate (FdUMP): a strategy to introduce nucleotides into hells. J. Med. Chem. 1994, 37, 3902-3909.

15. Tang, Y.-b.; Peng, Z.-g.; Liu, Z.-y.; Li, Y.-p.; Jiang, J.-d.; Li, Z.-r. Some new acyclic nucleotide analogues as antiviral prodrugs: Synthesis and bioactivities in vitro. Bioorg. Med. Chem. Lett. 2007, 17, 6350-6353.

16. Mackman, R.L.; Zhang, L.; Prasad, V.; Boojamra, C.G.; Douglas, J.; Grant, D.; Hui, H.; Kim, C.U.; Laflamme, G.; Parrish, J.; Stoycheva, A.D.; Swaminathan, S.; Wang, K.; Cihlar, T. Synthesis, anti-HIV activity, and resistance profile of thymidine phosphonomethoxy nucleosides and their bis-isopropyloxymethylcarbonyl (bisPOC) prodrugs. Bioorg. Med. Chem. 2007, 15, 5519-5528.

17. De Clercq, E.; Holy, A. Acyclic nucleoside phosphonates: A key class of antiviral drugs. Nat. Rev. Drug Discov. 2005, 4, 928-940.

18. Arimrilli, M.N.; Kim, C.U.; Dougherty, J.; Mulato, A.; Oliyai, R.; Shaw, J.-P.; Cundy, K.C.; Bischofberger, N. Synthesis, in vitro biological evaluation and oral bioavailability of 9-[2(phosphonomethoxy)propyl]adenine (PMPA) prodrugs. Antivir. Chemother. 1997, 8, 557-564.

19. Shaw, J.-P.; Sueoka, C.M.; Oliyai, R.; Lee, W.A.; Arimilli, M.N.; Kim, C.U.; Cundy, K.C. Metabolism and pharmacokinetics of novel oral prodrugs of 9-[(R)-2(phosphonomethoxy)propyl]adenine (PMPA) in dogs. Pharm. Res. 1997, 14, 1824-1829.

20. Villard, A.-L.; Coussot, G.; Lefebvre, I.; Augustijns, P.; Aubertin, A.-M.; Gosselin, G.; Peyrottes, S.; Perigaud, C. Phenyl phosphotriester derivatives of AZT: Variations upon the SATE moiety. Bioorg. Med. Chem. 2008, 16, 7321-7329.

21. Peyrottes, S.; Egron, D.; Lefebvre, I.; Gosselin, G.; Imbach, J.L.; Perigaud, C. SATE pronucleotide approaches: an overview. Mini-Rev. Med. Chem. 2004, 4, 395-408, and references therein.

22. Perigaud, C.; Gosselin, G.; Lefebvre, I.; Girardet, J.L.; Benzaria, S.; Barber, I.; Imbach, J.L. Rational design for cytosolic delivery of nucleoside monophosphates: "SATE" and "DTE" as 
enzyme-labile transient phosphate protecting groups.Bioorg. Med. Chem. Lett. 1993, 3, 2521-2526.

23. Routledge, A.; Walker, I.; Freeman, S.; Hay, A. Mahmood, N. Synthesis, bioactivation and antiHIV activity of 4-acyloxybenzyl bis(nucleoside-5'-yl) phosphates. Nucleos. Nucleot. 1995, 14, 1545-1558.

24. Srivastva, D.N.; Farquhar, D. Bioreversible phosphate protective groups: Synthesis and stability of model acyloxymethyl phosphates. Bioorg. Chem. 1984, 12, 118-129.

25. Farquhar, D.; Srivastva, D.N.; Kuttesch, N.J.; Saunders, P.P. Biologically reversible phosphateprotective groups. J. Pharm. Sci. 1983, 72, 324-325.

26. Mittchell, A.G.; Nicholls, D.; Walker, I.; Irwin, W.J.; Freeman, S. Prodrugs of phosphonoformate: Products, kinetics and mechanisms of hydrolysis of dibenzyl (methoxycarbonyl)phosphonate. $J$. Chem. Soc., Perkin Trans. 2 1991, 1297-1303.

27. Mitchell, A.G.; Thompson, W.; Nicholls, D.; Irwin, W.J.; Freeman, S. Bioreversible protection for the phospho group: bioactivation of the di(4-acyloxybenzyl) and mono(4-acyloxybenzyl) phosphoesters of methylphosphonate and phosphonoacetate. J. Chem. Soc. Perkin Trans. 1 1992, 2345-2353.

28. Thomson, W.; Nicholls, D.; Irwin, W.J.; Al-Mushadani, J.S.; Freeman, S.; Karpas, A.; Petrik, J.; Mahmood, N.; Hay, A.J. Synthesis, bioactivation and anti-HIV activity of the bis(4acyloxybenzyl) and mono(4-acyloxybenzyl) esters of the 5'-monophosphate of AZT. J. Chem. Soc., Perkin Trans. 1 1993, 1239-1245.

29. Ora, M.; Taherpour, S.; Linna, R.; Leisvuori, A.; Hietamaki, E.; Poijärvi-Virta, P.; Beigelman, L.; Lönnberg, H. Biodegradable protections for nucleoside 5'-monophosphates: Comparative study on the removal of $O$-acetyl and $O$-acetyloxymethyl protected 3-hydroxy-2,2bis(ethoxycarbonyl)propyl groups. J. Org. Chem. 2009, 74, 4992-5001.

30. Ora, M.; Mäki, E.; Poijärvi, P.; Neuvonen, K.; Oivanen, M.; Lönnberg, H. Hydrolytic stability of nucleoside phosphotriesters derived from bis(hydroxymethyl)-1,3-dicarbonyl compounds and their congeners: towards a novel pro-drug strategy for antisense oligonucleotides. J. Chem. Soc., Perkin Trans. 2 2001, 881-885.

31. Poijärvi, P.; Mäki, E.; Tomperi, J.; Ora, M.; Oivanen, M.; Lönnberg, H. Towards nucleotide prodrugs derived from 2,2-bis(hydroxymethyl)malonate and its congeners: hydrolytic cleavage of 2-cyano-2-(hydroxymethyl)-3-methoxy-3-oxopropyl and 3-(alkylamino)-2-cyano-2(hydroxymethyl)-3-oxopropyl protections from the internucleosidicphosphodiester and phosphorothioate linkages. Helv. Chim. Acta 2002, 85, 1869-1876.

32. Poijärvi, P.; Oivanen, M.; Lönnberg, H. Towards oligonucleotide prodrugs: 2,2bis(ethoxycarbonyl) and 2-(alkylaminocarbonyl)-2-cyano substituted 3-(pivaloyloxy)propyl groups as biodegradable protecting groups for internucleosidicphosphoromonothioate linkages. Lett. Org. Chem. 2004, 1, 183-188.

33. Poijärvi, P.; Heinonen, P.; Virta, P.; Lönnberg, H. 2,2-Bis(ethoxycarbonyl)- and 2(alkylaminocarbonyl)-2-cyano-substituted 3-(pivaloyloxy)propyl groups as biodegradable phosphate protections of oligonucleotides. Bioconjugate Chem. 2005, 16, 1564-1571. 
34. Erion, M.D.; van Poelje, P.D.; Mackenna, D.A.; Colby, T.J.; Montag, A.C.; Fujitaki, J.M.; Linemeyer, D.L.; Bullough, D.A. Liver-targeted drug delivery using HepDirectprodrugs. J. Pharmacol. Exp. Ther. 2005, 312, 554-560.

35. Casanova, M.; Heck, H. Further studies of the metabolic incorporation and covalent binding of inhaled [3H]- and [14C]formaldehyde in Fischer-344 rats: effects of glutathione depletion. Toxicol. Appl. Pharmacol. 1987, 89, 105-121.

36. Lu, K.; Ye, W.; Ball, A.G.L.M.; Swenberg, J.A. Formation of S-[1-(N2Deoxyguanosinyl)methyl]glutathione between Glutathione and DNA Induced by Formaldehyde. J. Am. Chem. Soc. 2009, 131, 3414-3415.

37. Guzaev, A.; Lönnberg, H. Bis(hydroxymethylation) of the active methylene group of 1,3dicarbonyl and related compounds. Synthesis 1997, 1281-1284.

38. Guzaev, A.; Salo, H.; Azhayev, A.; Lönnberg, H. Novel non-nucleosidic building blocks for the preparation of multilabeled oligonucleotides. Bioconjugate Chem. 1996, 7, 240-248.

Sample Availability: Samples of the compounds $\mathbf{1 , 8}$ and $\mathbf{1 0}$ are available from the authors.

(C) 2011 by the authors; licensee MDPI, Basel, Switzerland. This article is an open access article distributed under the terms and conditions of the Creative Commons Attribution license (http://creativecommons.org/licenses/by/3.0/). 